Jurnal Indonesia Sosial Teknologi:p-ISSN: 2723 - 6609

e-ISSN :2745-5254

Vol. 2, No.12 Desember 2021

\title{
PERANCANGAN SISTEM INFORMASI LAPORAN KEGIATAN BERBASIS WEB DI PT. AREON BANDUNG
}

\author{
Deden Bahrudin ${ }^{1}$, Ulul Izmi Badruzzaman ${ }^{2}$ \\ Politeknik Piksi Ganesha Bandung ${ }^{1,2}$ \\ Email: dedenbahrudin007@gmail.com ${ }^{1}$, ululizmibz@gmail.com²
}

\begin{abstract}
Abstrak
Penelitian ini bertujuan untuk menganalisis, merancang dan mengimplementasikan sistem informasi laporan kegiatan di PT AREON Bandung. Metode Penelitian yang digunakan adalah Kualitatif Deskriptif. Teknik pengumpulan data dengan cara melakukan pengamatan (observasi), wawancara, dan kajian Pustaka sesuai dengan topik masalah. Sedangkan metode pengembangan perangkat lunak menggunakan prototype. Dari penelitian yang telah dilakukan terdapat permasalahan yang terjadi, yaitu dalam melakukan pelaporan kegiatan menggunakan media kertas dan aplikasi standar sehingga sering terjadi kesalahan olah data bahkan sering terjadi data ganda. Dengan adanya permasalahan tersebut maka perlu adanya rancangan sistem informasi laporan kegiatan berbasis web yang diimplementasikan dengan bahasa pemrograman PHP dengan Framework Laravel serta My SQL sebagai database. Dengan adanya aplikasi sistem pelaporan kegiatan ini diharapkan menjadi lebih efektif dan efisien.
\end{abstract}

Kata kunci: Sistem informasi, Laporan Kegiatan, $P H P, M y S Q L$

\section{Abstract}

This study aimed to analyze, design and implement an activity reporting information system at PT AREON Bandung The research method used is descriptive qualitative. The technique of collecting data is by making observations, interviews, and literature studies according to the topic of the problem. While the software development method uses a prototype From the research that has been done, there are problems that occur, namely in reporting activities using paper media and standard applications so that data processing errors often occur and even double data occurs. With these problems, it is necessary to design a web-based activity reporting information system that is implemented in the PHP programming language with the Laravel Framework and MY SQL as a database. With the application of this activity reporting system, it is expected to be more effective and efficient.

Keywords: Information system; Activity Report; PHP; MySQL.

\section{Pendahuluan}

Teknologi informasi mempunyai peran penting dan membawa dampak positif dalam kehitupan manusia. Peradaban dunia telah memasuki era informasi setelah ditemukanya komputer pada tahun 1955. Dalam hal ini teknologi informasi berbasis 
komputer sangat membantu segala kegiatan dalam kehidupan manusia (Muhson, 2010). Hingga saat ini, sudah banyak sistem informasi dengan media komputer yang digunakan orang sebagai alat pengolah data untuk menghasilkan informasi yang dibutuhkan, salah satunya dalam sistem informasi pengolahan data laporan kegiatan.

Laporan kegiatan adalah bentuk pertanggung jawaban yang diberikan kepada atasan sebagai informasi atas terlaksananya suatu kegiatan (Afriansyah, 2019). Laporan kegiatan menjadi hal yang penting bagi perusahaan atau organisasi, dimana laporan kegiatan sebagai dasar kebijakan, pengarahan dan bahan penyusunan rencana kegiatan selanjutnya, serta untuk mengetahui perkembangan proses kegiatan tersebut.

PT. AREON Bandung terkhusus pada bagian tim AppOn yaitu tim yang menangani sistem pelaporan kegiatan dimana untuk melapor hasil kegiatan pekerjaan yaitu tidak adanya sistem yang menunjang untuk mengelola data kegiatan. Sistem berjalan dengan media kertas dan aplikasi standar Microsoft office dalam pencatatan laporan kegiatan pekerjaan, sehingga dirasakan kurang optimal.

Dalam hal ini menimbulkan adanya permasalahan terkait pencatatan kegiatan pelaporan mingguan yang sering terjadi data ganda dan mengalami ketidak efisiensinya pencarian data (Agustinus, 2019). Dengan semakin banyak data perusahan, data kegiatan yang masuk mengakibatkan terjadi penumpukan berkas, sehingga diperlukan sistem yang mampu mengatasi permasalahan tersebut.

Melihat keadaan tersebut, Penulis ingin mengembangkan sistem yang berjalan ke sistem elektronik dalam pengolahan data dengan membangun suatu program sistem aplikasi, sehingga akan menunjang kinerja lebih efektif dan efisien. Sistem tersebut dapat mengubah perilaku proses kegiatan yang mampu memberikan kemudahan pengelolaan data.

Dengan memanfaatkan teknologi informasi maka rancangan sistem aplikasi laporan kegiatan menjadi pilihan yang tepat. Dengan demikian maka Penulis tertarik untuk merancang sistem informasi Laporan kegiatan berbasis web menggunakan pemodelan Unified Modeling Languange (UML) dan di implementasikan dengan bahasa pemrograman PHP dengan MySQL sebagai sistem databasenya.

Perancangan merupakan suatu pola yang diciptakan untuk menjadi solusi dalam mengatasi masalah yang dihadapi baik oleh perusahaan, organisasi atau lembaga setelah dilakukan analisis terlebih dahulu. Menurut (Ladjamudin, 2013) Perancangan adalah suatu kegiatan yang memiliki tujuan untuk mendesain sistem baru yang dapat menyelesaikan masalah-masalah yang dihadapi perusahaan yang di peroleh dari pemilihan alternatif sistem yang terbaik.

Sistem Informasi menurut (Hutahaean \& Azhar, 2018) adalah Suatu system dalam suatu organisasi yang mempertemukan kebutuhan manaemen sehari-hari dari transaksi, penunjang operasi, manajemen, dan operasi.

Sedangkan menurut (Putra, 2020) Sistem informasi adalah komponen yang saling berhubungan dari proses menciptakan dan menyediakan informasi dalam suatu 
perusahaan, memproses input berupa sumber daya, yang kemudian diolah oleh perangkat keras, dan komponen perangkat lunak yang menghasilkan informasi sebagai output.

Tahapan Perancangan/desain sistem mempunyai tujuan utama, yaitu untuk memenuhi kebutuhan kepada pemakai sistem dan untuk memberikan gambaran yang jelas dan rancang bangun yang lengkap kepada pemrogram komputer dan ahli-ahli teknik yang terlibat.

Kegiatan adalah aktivitas, usaha, atau pekerjaan suatu peristiwa atau kejadian yang pada umumnya tidak dilakukan secara terus menerus. Penyelenggara kegiatan itu sendiri bisa merupakan badan, instansi pemerintah, organisasi, orang pribadi, lembaga, dan lain-lain. Biasanya kegiatan dilaksanakan dengan berbagai alasan tertentu. Laporan kegiatan merupakan sebuah laporan hasil dari suatu kegiatan, yang biasanya dibuat setelah kegiatan selesai. Melaporkan kegiatan biasanya membuat mereka menyebutkan kegiatan partisipasi (peserta).

Laravel adalah open souce PHP web framework yang dibuat oleh TaylorOtweel digunakan untuk pengembangan aplikasi web menggunakan arsitektur Model View Controller (MVC) (Taryanto, 2017).

Kerangka Laravel mudah dimengerti dan mudah dimengerti tentang otentikasi, routing, manajer sesi, caching dan kegunaan lain dari komponen laravel. Laravel juga menyediakan fitur seperti migrasi database dan unit tes dukungan integrase yang membuatnya mudah bagi pengembang untuk membangun aplikasi yang kompleks (Suryawinata, 2019).

Menurut (Nasir \& Solikin, 2018) "MySQL adalah sistem manajemen database SQL open source dan paling populer saat ini. Sistem database MySQL, mendukung berbagai fungsi,seperti multi-threaded, multi-user dan sistem manajemen database SQL DBMS Basis data dibuat untuk sistem basis data yang cepat, andal, dan mudah digunakan (Pahlevi, 2013).

\section{Metode Penelitian}

Dalam proses pengumpulan data penelitian, Penulis menggunakan metode penelitian kualitatif dengan pendekatan deskriptif, dimana menurut (Sugiyono, 2018), metode penelitian kualitatif adalah metode penelitian yang digunakan untuk penelitian pada kondisi objektif yang alamiah dimana peneliti adalah sebagai instrumen kunci, teknik penelitian data dilaksanakan secara gabungan, analisa data bersifat induktif, hasil penelitian lebih menekankan pada makna dari pada generalisasi. Dalam penelitian ini juga menggunakan metode penelitian deskriptif. yaitu gambaran semua data yang kemudian dianalisis dan dibandingkan berdasarkan kenyataan yang sedang berlangsung dan mencoba untuk memberikan pemecahan selanjutnya

Pada tahap Perancangan, Penulis menggunakan metode pengembangan prototype. Pada model prototype meliputi proses tahapan yaitu pengumpulan kebutuhan, perancangan dan evaluasi prototype. Selain itu, sistem akan diuji menggunakan metode black box. Metode black box ini bertujuan untuk memeriksa program setelah selesai 
dirancang, guna untuk mengetahui aplikasi berfungsi dengan baik, dan bekerja secara efisien. Dengan menentukan tujuan dan kebutuhan, kemudian membuat perancangan laporan kegiatan yang dibangun agar dapat berjalan dengan baik pada tahap implementasi dan melakukan evaluasi prototype perancangan sistem informasi yang dibuat.

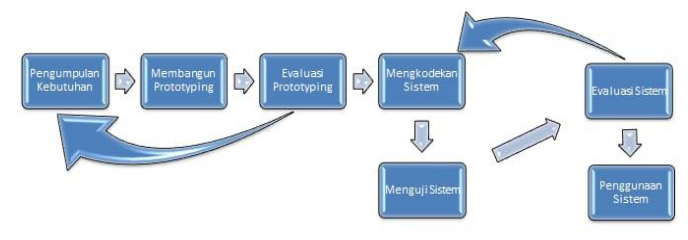

\section{Gambar 1. Ilustrasi Model Prototyping}

Adapun Tahapan-tahapan Prototyping antara lain sebagai berikut :

a. Analisa Kebutuhan : Pada tahap ini pengembang melakukan analisa, identifikasi software dan semua kebutuhan system yang akan dibuat.

b. Membangun Prototyping : tahap ini membangun prototyping dengan membuat perancangan sementara yang berfokus penyajian kepada pengguna dengan membuat input dan output.

c. Evaluasi Prototyping : evaluasi dilakukan untuk mengetahui apakah prototyping sudah sesuai dengan yang diharapkan pelanggan.

d. Pengkodean Sistem : tahap ini prototyping yang sudah dibangun dan disetujui akan diubah ke dalam Bahasa pemograman yang sesuai.

e. Menguji Sistem : tahap ini diperlukan pengujian system untuk menguji system perangkat lunak yang sudah dibuat.

f. Evaluasi Sistem : pada tahap ini perangkat lunak yang sudah jadi akan dievaluasi pengguna untuk mengetahui apakah system berjalan sesuai yang diharapkan.

g. Penggunaan system/Implementasi system : tahap ini perangkat lunak yang sudah diuji dan disetujui oleh pengguna siap untuk digunakan.

Adapun teknik pengumpulan data pada penelitian ini dengan Observasi atau pengamatan langsung di lokasi PT. Aeron Bandung, wawancara dengan pegawai atau pihak terkait pada objek penelitian, dan kajian pustaka.

\section{Hasil dan Pembahasan}

Rancangan sistem laporan kegiatan dibuat dengan pengembangan berorientasi objek menggunakan $U M L$ yang berfungsi sebagai perancangan, dokumentasi dan visualisasi (Prihandoyo, 2018).

\section{A. Perancangan Sistem Informasi}

\section{Diagram Use Case}

interaksi yang saling berkaitan antara sistem dan aktor. Use case dijalankan melalui cara menggambarkan tipe interaksi antara user suatu program (sistem) dengan sistemnya sendiri. Diagram use case untuk aplikasi laporan kegiatan dapat dilihat pada gambar berikut. 


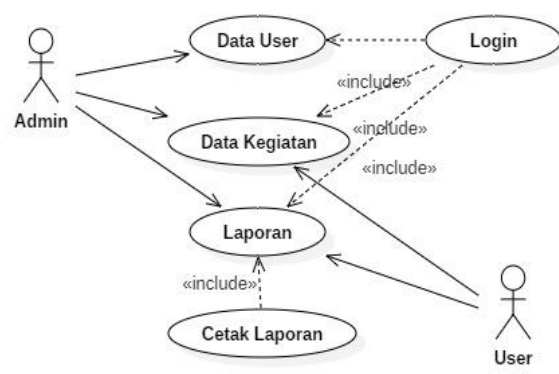

Gambar 2. Use Case Diagram Sistem Laporan Kegiatan

Disini terdapat dua actor yaitu admin dan User. Admin mengelola jenis menu yaitu Mengelola Data User, Data Kegiatan dan Data Laporan. Kemudian admin melakukan proses Kelola User, Melakukan Proses Kelola Kegiatan, Melakukan Proses kelola Cetak Laporan Kegiatan.

\section{Diagram Activity}

Diagram aktivitas menggambarkan aliran kerja atau aktifitas dari sebuah sistem atau proses bisnis atau menu yang ada pada perangkat lunak. Diagram aktifitas menggambarkan aktifitas sistem bukan apa yang dilakukan oleh actor. Diagram aktivitas untuk aplikasi Laporan Kegiatan untuk admin dapat dilihat pada gambar berikut

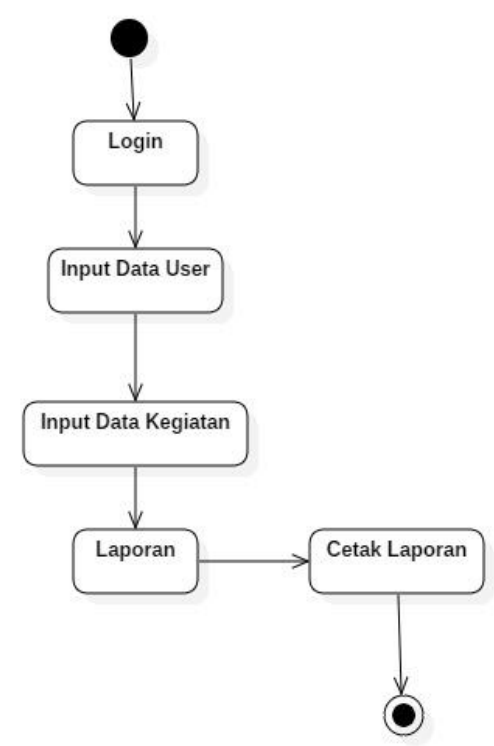

Gambar 3. Activity Diagram Sistem Laporan Kegiatan

Terdapat Lima aktivitas dari diagram aktivitas yang diusulkan yaitu aktivitas login, aktivitas Input data user, input data kegiatan, Input Data laporan dan cetak laporan.

\section{Diagram Kelas}


Diagram kelas menjelaskan struktur sistem dari segi pendefinisian class-class yang akan dibuat untuk membangun sebuah sistem Satzinger (2011:28). Diagram kelas untuk aplikasi Laporan Kegiatan untuk admin dapat dilihat pada gambar berikut.

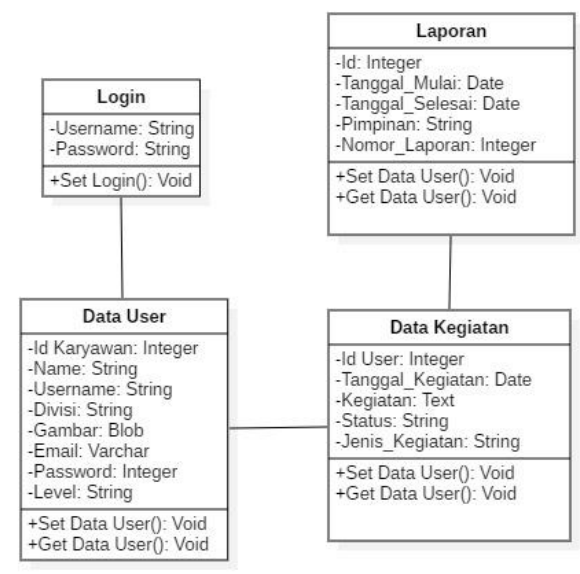

\section{Gambar 4. Diagram Kelas Sistem Laporan Kegiatan}

Pada diagram kelas terdapat empat kelas yang terdiri dari kelas login, kelas data user, kelas data kegiatan, dan kelas laporan. Kelas login memiliki atribut username dan password, kelas data user memiliki atribut id karyawan, name, username, divisi, gambar, email, password, dan level. kelas data kegiatan memiliki atribut id user, tanggal kegiatan, kegiatan, status, dan jenis kegiatan. Kelas laporan memiliki atribut id, tanggal mulai, tanggal selesai, pimpinan dan nomor laporan.

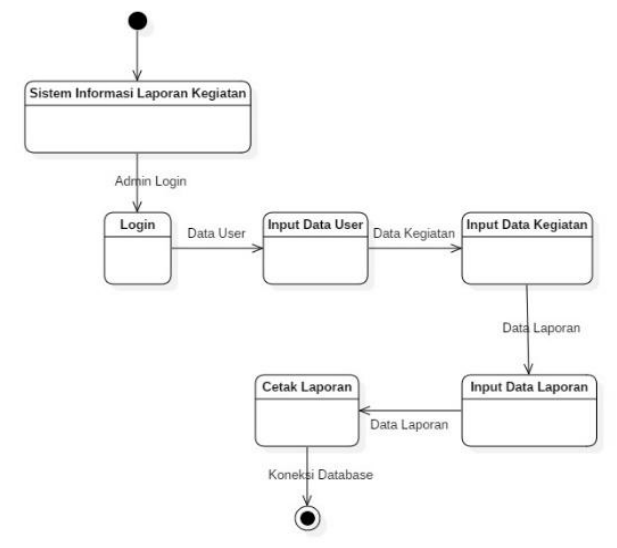

\section{Gambar 5. Statechart Sistem Laporan Kegiatan}

Pada statechart ada 5 state yang diusulkan yaitu dimulai dari state login, state input data user, statse input data kegiatan, input data laporan, dan cetak laporan.

\section{B. Implementasi Sistem Informasi}

\section{Tampilan Sistem Login}

Form login dibuat untuk memvalidasi user yang diberikan hak akses terhadap aplikasi laporan kegiatan di PT. AREON yang ditunjukkan pada gambar berikut: 
Perancangan Sistem Informasi Laporan Kegiatan Berbasis WEB di PT. Areon Bandung

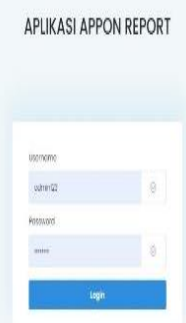

\section{Gambar 6. Form Login}

Input dari Form Login yaitu username dan password, Admin untuk hak akses ke menu admin. Akun akan di validasi ketika button Login di click.

\section{Halaman Menu}

Form menu ditunjukan pada gambar 7 .

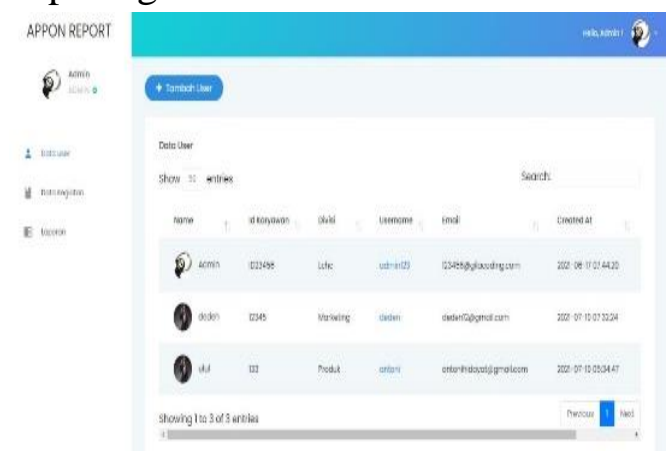

\section{Gambar 7. Form Menu}

Form menu langsung menunjukan ke data user ketika admin masuk, dan ketika user masuk langsung di tunjukan ke data kegiatan.

\section{Halaman Menu Data Kegiatan}

Menu data kegiatan ditunjukan pada gambar 8. Dan form data kegiatan ditunjukan pada gambar 9

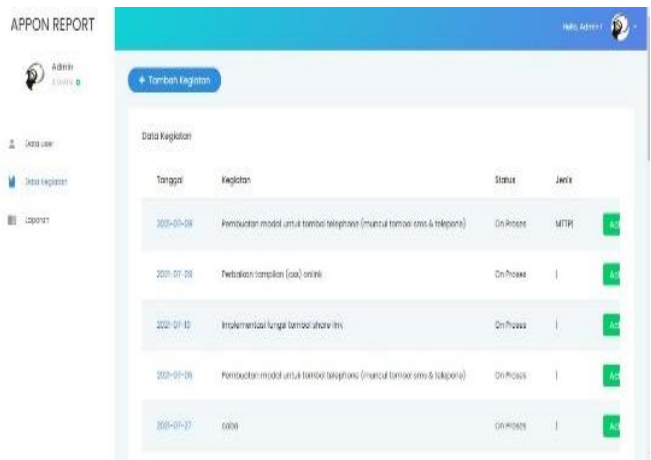

Gambar 8. Tampilan Menu Data Kegiatan 


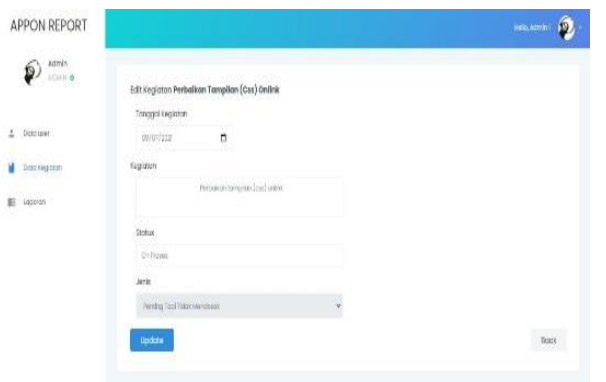

Gambar 9. Tampilan Form Data Kegiatan

\section{Halaman Menu Data Laporan}

Menu data Form Laporan tampilan ditunjukan pada gambar 10. Dan Hasil Data Laporan ditunjukan pada gambar 11

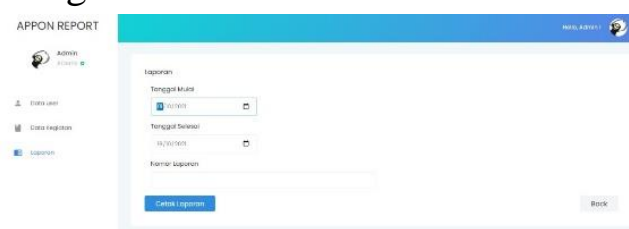

\section{Gambar 10. Tampilan Form data Laporan}

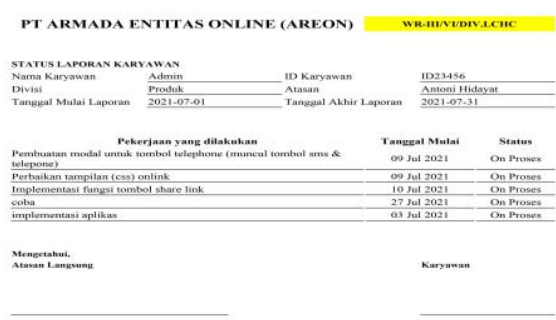

\section{Gambar 11. Tampilan Pdf Laporan Kegiatan}

\section{Spesifikasi Hardware dan Software}

\section{Perangkat Keras (Hardware)}

Untuk mendukung kinerja sistem informasi Laporan kegiatan berbasis web di PT AREON Bandung dibutuhkan spesifikasi perangkat keras (Hardware) agar sistem berjalan dengan baik. Berikut adalah spesifikasi yang disarankan:

\begin{tabular}{cc} 
Tabel 1 Spesifikasi Hardware \\
\hline Hardware & \multicolumn{1}{c}{ Contoh } \\
& Hardware \\
\hline Processor & Intel Pentium \\
& Dual Core
\end{tabular}


Perancangan Sistem Informasi Laporan Kegiatan Berbasis WEB di PT. Areon Bandung

\begin{tabular}{ll}
\hline & $\begin{array}{l}\text { atau lebih } \\
\text { tinggi }\end{array}$ \\
\hline RAM & 4 GB atau \\
& lebih tinggi \\
\hline Hardisk & $\begin{array}{l}500 \text { GB atau } \\
\text { lebih tinggi }\end{array}$ \\
\hline Keyboard & $\begin{array}{l}\text { Kompatible } \\
\text { dengan Ms. }\end{array}$ \\
& Windows \\
\hline Mouse & Kompatible \\
& dengan $M s$. \\
& Windows \\
\hline
\end{tabular}

\section{Perangkat Lunak (Software)}

Dalam perancangan, sistem informasi laporan kegiatan berbasis web membutuhkan perangkat lunak (software) sebagai pendukung untuk kebutuhan program (Ogedebe \& Jacob, 2012). Adapun spesifikasi perangkat lunak (software) untuk membangun sistem yang dirancang sebagai berikut:

Tabel 2 Spesifikasi Software

\begin{tabular}{ll}
\hline \multicolumn{1}{c}{ Hardware } & \multicolumn{1}{c}{ Contoh Hardware } \\
\hline Sistem Operasi & Ms Windows 7 atau lebih tinggi \\
\hline Pemograman & $P H P$ \\
\hline Pengolahan Database & $M y S Q L$ \\
\hline Web Server & XAMPP \\
\hline
\end{tabular}

\section{Kesimpulan}

Sistem informasi yang berjalan saat ini menggunakan media kertas catatan dan aplikasi Microsoft office. Pengolahan data tidak tersistem baik dan untuk mengolah data menjadi informasi dibutuhkan waktu yang relatif lama sehingga proses ini kurang efisien.

Sistem pelaporan kegiatan memerlukan sebuah sistem aplikasi berbasis web guna membantu kinerja pegawai lebih efektif.

Rancangan sistem informasi laporan kegiatan menggunakan bahasa pemrograman PHP dengan Framework Laravel serta My SQL sebagai database yang diharapkan menjadi solusi bagi Perusahaan. 


\section{Bibliografi}

Afriansyah, Hade. (2019). Administrasi Keuangan.

Agustinus, Sulasno. (2019). Implementasi Sistem Informasi Administrasi Kependudukan (SIAK) dalam Proses Pelayanan Kartu Tanda Penduduk (KTP) Pada Dinas Kependudukan dan Pencatatan Sipil (Suatu Penelitian Deskriptif Kualitatif Di Dinas Kependudukan Dan Pencatatan Sipil Kabupaten Gunung Kidul Daerah Istimewa Yogyakarta).

Hutahaean, Jeperson, \& Azhar, Zulfi. (2018). Sistem Informasi Laporan Penilaian Barang Milik Negara Berbasis Web (Studi Kasus: KPKNL KISARAN). Riau Journal of Computer Science, 4(2), 19-30. https://doi.org/10.30606/rjocs.v4i2.1627

Ladjamudin, Al Bahra Bin. (2013). Analisis dan Desain Sistem Informasi, Graha ilmu. Yogyakarta.

Muhson, Ali. (2010). Pengembangan media pembelajaran berbasis teknologi informasi. Jurnal Pendidikan Akuntansi Indonesia, 8(2). https://doi.org/10.21831/jpai.v8i2.949

Nasir, Muhammad, \& Solikin, Imam. (2018). Rancang Bangun E-Commerce Toko Raffamart Palembang Menggunakan Macromedia Dreamweaver. Jurnal Ilmiah Matrik, 20(3), 247-257. https://doi.org/10.33557/jurnalmatrik.v20i3.473

Ogedebe, Peter M., \& Jacob, Babatunde Peter. (2012). Software Prototyping: A Strategy to Use When User Lacks Data Processing Experience.

Pahlevi, Said Mirza. (2013). Tujuh Langkah Praktis Pembangunan Basis Data. Elex Media Komputindo.

Prihandoyo, M. Teguh. (2018). Unified Modeling Language (UML) Model Untuk Pengembangan Sistem Informasi Akademik Berbasis Web. Jurnal Informatika: Jurnal Pengembangan IT, 3(1), 126-129. http://dx.doi.org/10.30591/jpit.v3i1.765

Putra, Socrates Sullivan Riadi. (2020). Rancang Bangun Penerapan Fitur Sistem Informasi Geografis pada Aplikasi Kredit Perusahaan Pembiayaan Kredit Berbasis Android dan Website (Studi Kasus: PT Emas Persada Finance)/Socrates Sullivan Riadi Putra/56150543/Pembimbing: Akhmad Budi.

Sugiyono. (2018). Metode Penelitian Kuantitatif, Kualitatif, dan R\&D. Bandung: Alfabeta.

Suryawinata, Mohammad. (2019). Buku Ajar Mata Kuliah Pengembangan Aplikasi Berbasis Web. Umsida Press, 1-144. https://doi.org/10.21070/2019/978-602-5914$\underline{81-2}$

Taryanto, Ardi. (2017). Letters Of Payments Application System Using RAD Studio XE2 
Perancangan Sistem Informasi Laporan Kegiatan Berbasis WEB di PT. Areon Bandung

(Case Study: BANDUNG PUBLIC WORKS DEPARTMENT). Jurnal E-Komtek (Elektro-Komputer-Teknik), 1(1), 1-11. 